\title{
Investigation on the Utilization Of Coal Washery Rejects By Different Microbial Sources For Biogenic Methane Production
}

\section{Vinitha Ponnudurai}

Bannari Amman Institute of Technology Department of Biotechnology

Ravikumar Rajarathinam ( $\nabla$ drravibit@gmail.com )

Bannari Amman Institute of Technology Department of Biotechnology

KirupaSankar Muthuvelu

Bannari Amman Institute of Technology Department of Biotechnology

Sivasubramanian Velmurugan

National Institute of Technology, Calicut

Radha Krishna Nalajala

Singareni Collieries Company Limited

Loganathan Arumugam

Singareni Collieries Company Limited

Research

Keywords: Coal washery rejects, Singareni Coal mines, Methane (CH4), Cow dung, Biostimulation

Posted Date: April 12th, 2021

DOI: https://doi.org/10.21203/rs.3.rs-389407/v1

License: (1) This work is licensed under a Creative Commons Attribution 4.0 International License.

Read Full License

Version of Record: A version of this preprint was published at Chemosphere on January 1st, 2022. See the published version at https://doi.org/10.1016/j.chemosphere.2021.132165. 


\section{Abstract}

High energy consumption and depletion of fossil fuels lead to the introduction of new technologies to produce alternative fuels with fewer emissions of greenhouse gases. The present investigation was focused to utilize the waste coal washery rejects as a substrate to produce biogenic methane under optimum conditions. Experiments were performed to explore the efficiency of non-coal samples (cow dung, distillery anaerobic digester sludge) and coal mines enriched samples in the degradation of coal washery rejects. Further cow dung, distillery anaerobic sludge, and coal washery rejects were taken at various concentrations to develop anaerobic slurry with the capacity to grow under coal. Whereas the anaerobic slurry which contains 1:1:1 of cow dung, distillery anaerobic sludge, and coal washery rejects produced methane of around $55.7 \%$. The coal enriched samples showed the maximum of $22.6 \%$ of methane. Subsequently, the best methane-producing anaerobic non-coal consortiums were compared with coal enriched microbial culture in converting coal washery rejects of $10 \mathrm{~g} / \mathrm{l}$ to methane. Results revealed that cow dung inoculum and coal mine enriched inoculum source produced the nearly same amount of methane. This study suggested that the selected anaerobic slurries and coal enriched sample can utilize sub-bituminous coal washery rejects in methane production. Thus, these consortiums can be applied in converting a large amount of coal washery rejects into methane thus can lead to the reclamation of the site.

\section{Introduction}

The rapid increase in the consumption of energy resources leads to the exhaustion of conventional fossil fuels. In India, the consumption of energy from conventional sources like coal, lignite, crude petroleum, natural gas, and nuclear sources are increasing gradually. The total energy consumption during 2018 has increased from 739.34 MT to 897.34 MT (Metric Tons) from previous years (Energy Statistics 2019). This gradual increase will lead to the depletion of conventional resources, thus consequent finding of alternative sources for energy generation is essential. The report states that coal accounts for about $44 \%$ of India's total energy consumption and notably India places the third rank in producing coal. Indian Coal deposits are found in Odisha, Jharkhand, Maharashtra, West- Bengal, Madhya Pradesh, Chhattisgarh, and Andhra Pradesh (Shadman and Md Aquil. 2014). Coal production is only about $947.06 \mathrm{MT}$, although the demand during the year 2018-19 is around 991.35 MT (Ministry of Coal annual report 2018-2019). This massive amount will be utilized for electricity generation, steel, and cement industries.

As per the IEA report, Indian Coal is of low quality with $45 \%$ ash content and low calorific value (2500$5000 \mathrm{kcal} / \mathrm{kg}$ ) (IEA 2002). To make this coal fit for industrial use, these coals must be washed, which is the most important part of coal beneficiation. The report of Energy Statistics states that nearly 53 washeries in India with a capacity of 132.2 MTY (Milliion Tonnes Per Year) are in operation that emits a high amount of coal washery rejects (Energy statistics 2019). During the coal beneficiation process,

several million tons of coal washery rejects get accumulated that becomes a major environmental hazard in the coal mines. Since the deposition of the coal rejects in the environment leads to self-combustion, it became a great disadvantage of coal washing. Thus these coal rejects are being used in industries for 
the generation of power using fluidized bed technology. The calorific values of the reject coal vary for different types of coal, which is the major limitation in the utilization of washery rejects in FBC boilers. Hence there is a need for discovering many diverse technologies for the reclamation of the site.

Biogas is the renewable form of energy that is produced by the anaerobic digestion of organic matter. Biogas is a combustible gas with nearly $60 \%$ of $\mathrm{CH}_{4}, 37 \% \mathrm{CO}_{2}$, and $3 \% \mathrm{H}_{2} \mathrm{~S}$ with the limited concentration of sulphur dioxide (Babel et al. 2009). As it can substitute the usage of fossil fuels, biogas from several sources is being investigated by researchers. Still now, substrates like manure, food waste, energy crops, rumen waste are being used as the substrate for biogas production (Hasan et al. 2018) (Liu et al. 2015). In recent years many studies are being focused on analyzing the potential of various coal seams to produce methane. Coal of various ranks like bituminous (Wang et al. 2016), (Rathi et al. 2015), subbituminous (Jones et al. 2008) (Fuertez et al. 2017), and lignite (Wang et al. 2017) are being used as substrate.

Several coal beds that produce methane are of biogenic origin, where microbial communities play a major role in the conversion of coal to methane. It has been reported that, in the U.S two CBM of Forest City and Powder River basin (Flores et al. 2008) and Indonesian coal bed (Susilawati et al. 2016) are of biogenic origin. So the microorganisms in coal beds have the potential to convert the coal into simpler compounds, then further into biogas. Microbial communities from the production water of coal mines and coal samples have fermentative bacteria like Firmicutes, Actinobacteria, Proteobacteria, and Bacteroidetes for coal degradation and the methanogens for the methanogenesis process (Wei et al. 2014). There is an increased interest in enhancing the production of biogenic methane through the bioaugmentation of adding non-coal consortium (Fuertez et al. 2017) and the bio-stimulation process of adding supplementary nutrients (Zhang and Liang 2017).

Many studies focused on enhancing methane production from coal using additional consortium or additional synthetic nutrients. Several co-digestion studies using mixed substrates like sheep dung, cow manure, rumen, municipal solid waste, wheat straw, and waste paper have been recorded (Li et al. 2018) (Liu et al. 2015). Thus, this study focuses on co-digesting the methane-producing substrates cow dung and distillery anaerobic digester sludge, which has an indigenous microbial consortium along with the coal washery rejects for maximal methane production. Further, these consortiums were compared with the coal mine microbial consortium in the conversion of coal washery rejects to methane. Several studies have been done on the microbial conversion of coal (Wang et al. 2019) and coal waste materials (Opara et al. 2012) (Zheng et al. 2017) into methane. This is the first report where coal washery rejects has been utilized to produce methane using various coal and non-coal microbial consortiums.

\section{Materials And Methods}

\subsection{Feedstock coal washery rejects}


Coal washery rejects were collected from Singareni Collieries Company Ltd (SCCL), Telangana, India (coordinates: $17^{\circ} 58 \rrbracket 21.7 \rrbracket / 80^{\circ} 44 \rrbracket 47.3 \rrbracket$ ). The mining area is located near the Manuguru area, Bhadradri Kothagudem district (Fig. 1). The bottom hole with a depth of $1000 \mathrm{~m}$, and the underground temperature was $68^{\circ} \mathrm{C}$. The coal washery rejects sample was obtained during washing the subbituminous coal to reduce the ash percentage present in the coal. The sample was dried and ground using mortar and pestle. The coal which passed through 60 mesh sieve was used as the substrate. To compare the geochemical properties of coal washery rejects with the raw coal available in the mining area, the raw coal was collected from the site. The properties of coal washery reject and coal (proximate and ultimate analysis) was done at the Indian Institute of Chemical Technology, Hyderabad.

\subsection{Collection of Inoculum source}

The inoculums sources collected for the study was cow dung and distillery anaerobic digester sludge. Fresh cow dung was collected to use as the inoculum source. Distillery Anaerobic Digester sludge was collected from the Bannari Amman Sugars industry at erode district, Tamil Nadu where they utilize distillery spent wash as substrate. The sludge was collected from the outlet of the anaerobic digester in the pre-sterilized airtight bottles containing $2 \% \mathrm{Na}_{2} \mathrm{~S}$. The bottles were sealed and transported into the laboratory within $24 \mathrm{~h}$ and stored at $4^{\circ} \mathrm{C}$.

The other sources used in this study to isolate the methanogenic consortium were the raw coal samples from four different sites in Singareni Collieries respectively. The coal samples were collected into a presterilized airtight container. The containers filled with nitrogen gas were dumped in the underground of selected areas for nearly 2 days. After 2 days all the samples were taken, in which again nitrogen gas was passed, sealed, transported to the laboratory and stored at $4^{\circ} \mathrm{C}$ to use as inoculums.

\subsection{Generation of Enrichment Cultures}

Two different experiments were established to generate the methanogenic consortium to use the coal washery rejects as substrate. Several non-coal microbial sources have the potential microbial consortium to produce biogas from complex polymers. So in one experiment the most recognized biogas producing inoculum sources cow dung and distillery anaerobic digester sludge were used along with the coal washery reject. This was performed to create the non-coal consortium with the capacity to degrade coal washery rejects.

The biogenic methane in coal beds (CBM) is produced by the microbial communities present in the coal bed seams. So the coal bed consists of potential microbes to convert coal to methane. So the other experiment focuses on the isolation of microbial consortium for methane production from the coal samples obtained from coal mines.

\subsubsection{Screening of Coal degrading consortium using different sources}


The anaerobic digester setup used for this study was the serum bottles with a rubber stopper and crimp cap. Two different setups were made to isolate the consortium from the coal and non-coal sources. The non-coal sources like cow dung (CR1) and anaerobic digester sludge (CR2) were mixed in sterilized distilled water in the ratio of 1:2 to the total volume of $90 \mathrm{ml}$ in duplicate. The Coal washery rejects along with cow dung and distillery anaerobic digester sludge were taken at different ratios (Table 1) to create the potential non-coal consortium which can survive in the coal washery rejects. These coal washery rejects and mixed cultures were designated as CR3, CR4, CR5, CR6, CR7, CR8, CR9, and CR10. In these studies, the cow dung and anaerobic sludge were used as both substrate and inoculums whereas dried coal washery reject was used only as substrate.

The isolation of methanogenic consortium from the raw coal source was executed using the enrichment culture technique. The modified mineral medium was prepared which contains the following minerals $\mathrm{KH}_{2} \mathrm{PO} 4 ; 0.25 \mathrm{~g} / \mathrm{l}, \mathrm{NaCl} ; 0.5 \mathrm{~g} / \mathrm{l}, \mathrm{MgCl}_{2} \cdot 6 \mathrm{H}_{2} 0 ; 0.2 \mathrm{~g} / \mathrm{l}, \mathrm{CaCl}_{2} .2 \mathrm{H}_{2} 0 ; 0.025 \mathrm{~g} / \mathrm{l}, \mathrm{NaHCo}_{3} ; 0.2 \mathrm{~g} / \mathrm{l}$ and yeast extract; $0.5 \mathrm{~g} / \mathrm{l}$ (Lavania et al. 2014). Sodium acetate at the final concentration of $2.5 \mathrm{~g} / \mathrm{l}$ and $50 \%(\mathrm{v} / \mathrm{v})$ methanol of $10 \mathrm{ml} / \mathrm{l}$ was added as the substrate to the medium and $\mathrm{pH}$ was adjusted to 7.00 . The indicator used in this medium was $100 \mu \mathrm{l}$ of resazurin. The reducing agents $(0.5 \mathrm{~g} / \mathrm{l} \mathrm{L-Cysteine} \mathrm{Hydrochloride} \mathrm{and} \mathrm{Sodium}$ sulphide) were added to the medium to remove the dissolved oxygen. The $\mathrm{O}_{2}$ free $\mathrm{N}_{2}$ flushed serum bottles were filled with $45 \mathrm{ml}$ of medium and sterilized. For enriching the growth of methanogens from the coal, sodium acetate, methanol, and $\mathrm{H}_{2}: \mathrm{CO}_{2}$ were added as the substrate which stimulates the production of biomethane (Raudsepp et al. 2017). The coal sources for isolation of methanogenic consortium taken for this study were designated as CR11, CR12, CR13, and CR14. Each sample of $30 \mathrm{~g}$ was inoculated in the nutrient medium under aseptic conditions.

Finally, all the experimental bottles were pressurized with $\mathrm{N}_{2}: \mathrm{CO}_{2}(80: 20)$ gas mixture to create a complete anaerobic condition. All the samples were incubated for 40 days at $37^{\circ} \mathrm{C}$ and shaken every day for $2 \mathrm{~min}$. The percentage of $\mathrm{CH}_{4}$ and $\mathrm{CO}_{2}$ in the headspace gas produced was quantified. The cultures which produce maximum methane were selected for further experiments. The potential of the selected cultures was analyzed by adding them as the inoculums for coal washery rejects.

Table 1. Experimental setup of coal and non-coal inoculums for isolation of microbial consortium 


\begin{tabular}{|c|c|c|c|c|c|}
\hline S.No & Consortium & $\begin{array}{l}\text { Coal Washery } \\
\text { Rejects } \\
\text { (g) }\end{array}$ & $\begin{array}{l}\text { Distillery Anaerobic digester } \\
\text { Sludge (g) }\end{array}$ & $\begin{array}{l}\text { Cow } \\
\text { Dung } \\
\text { (g) }\end{array}$ & $\begin{array}{l}\text { Raw Coal } \\
\text { (g) }\end{array}$ \\
\hline \multicolumn{6}{|c|}{ Non - Coal Inoculums } \\
\hline 1 & CR1 & - & - & 30 & - \\
\hline 2 & CR2 & - & 30 & - & - \\
\hline 3 & CR3 & 30 & - & - & - \\
\hline 4 & CR4 & 15 & - & 15 & - \\
\hline 5 & CR5 & 15 & 15 & - & - \\
\hline 6 & CR6 & 10 & 10 & 10 & - \\
\hline 7 & CR7 & 18 & - & 12 & - \\
\hline 8 & CR8 & 24 & - & 6 & - \\
\hline 9 & CR9 & 18 & 6 & 6 & - \\
\hline 10 & CR10 & 24 & 3 & 3 & - \\
\hline \multicolumn{6}{|c|}{ Coal Inoculums } \\
\hline 11 & CR11 & - & - & - & 30 \\
\hline 12 & CR12 & & & & 30 \\
\hline 13 & CR13 & - & - & - & 30 \\
\hline 14 & CR14 & - & - & - & 30 \\
\hline
\end{tabular}

\section{*CR - Consortium}

\subsection{Measurement of Biogas Produced}

The composition of methane (\%) and carbon dioxide (\%) in the gas produced was analyzed using a biogas analyzer (Biogas 5000 - Geotech Instruments (UK) Ltd) (Kafle and Kim 2011; Nghiem et al. 2014). The $\mathrm{CH}_{4}$ and $\mathrm{CO}_{2}$ were analyzed by a dual wavelength infrared sensor with the reference channel. The analyzer was calibrated using standard gas mixtures where mixture 1 contains $5 \% \mathrm{CH}_{4}$ and $10 \% \mathrm{CO}_{2}$, mixture 2 was with $60 \% \mathrm{CH}_{4}$ and $40 \% \mathrm{CO}_{2}$, and mixture 3 contains $5 \% \mathrm{CH}_{4}, 5 \% \mathrm{CO}_{2}$, and $6 \% \mathrm{O}_{2}$. The nitrogen gas was used as the balance gas in the above mixtures for calibration.

\subsection{Effect of various consortiums on coal as the sole carbon source}

In this research, most available raw materials like cow dung and anaerobic digester sludge has been used along with coal washery rejects. The production from the mixture has been noted. But the major concern 
of this research is to explore the biomethane potential of coal washery rejects alone, so here neglecting other substrates like cow dung and anaerobic digester sludge, coal washery reject is used as the sole source for the biogas production. For this study, the non-coal consortiums which produce a higher amount of methane CR1, CR4, CR6, CR7, and coal consortiums CR11, CR12, CR13, and CR14 were selected for evaluating the methane production. In this study, three sets of experiments were conducted.

a. $45 \mathrm{ml}$ of modified mineral medium with yeast extract (Lavania et al. 2014) was filled in the serum bottle with $10 \mathrm{~g} / \mathrm{l}$ of coal washery rejects.

b. $45 \mathrm{ml}$ of medium with $10 \mathrm{~g} / \mathrm{l}$ of coal washery rejects which does not contain any other additional sources.

c. The other set is considered as control where $45 \mathrm{ml}$ mineral medium which contains yeast extract is taken for inoculation of cultures. This does not contain any coal washery rejects.

To the above mentioned experimental setup, $5 \mathrm{ml}$ selected cultures were inoculated with the aseptic syringe and then incubated for 30 days. The $\mathrm{CH}_{4}$ and $\mathrm{CO}_{2}$ of the cultures were studied periodically.

\section{Results And Discussion}

\subsection{Properties of Coal Washery Rejects}

Coal washery rejects obtained by washing the sub-bituminous coal. The Ultimate analysis of the coal washery rejects revealed that it has low carbon $(21.9 \%)$ and oxygen content $(7.2 \%)$ compared to that present in raw coal obtained from the coal mines (Table 2). This less carbon content makes it inappropriate for the combustion process, thus it is being discarded as waste. But the recovery of the remaining carbon present in it is possible in the biogenic method. So this study considers the production of biogenic methane from the coal washery rejects.

Table 2. Proximate and Ultimate analysis of raw coal and coal washery rejects 


\begin{tabular}{|lll|}
\hline Properties & Raw Coal from coal mines (\% Wt) & Coal washery rejects (\% Wt) \\
\hline Proximate Analysis & & \\
\hline Moisture & 2.13 & 2.52 \\
\hline Ash & 32.98 & 67.46 \\
\hline Ultimate analysis & $\% \mathrm{Wt}$ & $\% \mathrm{Wt}$ \\
\hline Carbon & 77.87 & 21.9 \\
\hline Hydrogen & 5.34 & 0.37 \\
\hline Nitrogen & 1.5 & 0.39 \\
\hline Sulfur & 0.25 & 0.27 \\
\hline Oxygen & 12.02 & 7.2 \\
\hline
\end{tabular}

\subsection{Screening of Coal degrading consortium}

\subsubsection{Microbial Consortium from non-coal sources}

The inoculum sources cow dung (CR1), distillery anaerobic digester sludge (CR2), coal washery rejects (CR3), raw coal samples (CR11, CR12, CR13, CR14) and mixed cultures (CR4, CR5, CR6, CR7, CR8, CR9, and $\mathrm{CR} 10$ ) were prepared to generate potential consortium which produce $\mathrm{CH}_{4}$ and $\mathrm{CO}_{2}$. The production of methane shows the growth of microbes present in the sample. The $\mathrm{CH}_{4}$ and $\mathrm{CO}_{2}$ production in the digesters was recorded after 40 days. All the digester samples produced methane in which the highest methane obtained in CR6 was about $55.7 \%$ where cow dung, anaerobic digester sludge, and coal washery rejects were mixed at equal ratios (1:1:1) (Fig. 2). The result is comparable with other co-digestion studies where four different substrates mixed at equal ratios produced maximum methane (Gaur and Suthar 2017).

Next to CR6, the highest methane of $52 \%, 48.4 \%$, and $46.8 \%$ were produced in CR7, CR1, and CR4 samples respectively. The $\mathrm{CO}_{2}$ produced along with $\mathrm{CH}_{4}$ in these slurry samples were nearly $37 \%$. Here the codigested sample CR6, CR7, and CR4 produced the highest methane. Whereas mono-digested samples CR1, CR2, CR3 produced comparatively lesser $\mathrm{CH}_{4}$ of $48.4 \%, 8.5 \%$, and $0.2 \%$. Similar to this study (Li et al. 2018) researchers reported that co-digestion of sheep dung and waste paper enhanced the methane yield compared to mono-digested samples as it has the combination of two different substrates.

The CR3 sample produced a very fewer amount of methane $(0.2 \%)$ compared to other samples. The reason behind this reduction was the process carried out during the generation of coal washery rejects. Coal undergoes a beneficiation process to reduce the ash content that leads to the accumulation of coal washery rejects. During the process of beneficiation, the coal was washed several times before dumping in the open environment. The methanogens are found only in anoxic habitats (Enzmann et al. 2018) and 
they are obligate anaerobes. In the process of coal washing, the anoxic organisms present in the coal washery rejects would be eliminated. So this coal washery rejects can only be utilized as the substrate.

In this anaerobic digestion study, we aim to produce the potential consortium which can convert coal washery rejects into methane. Therefore we have taken a maximum of $30 \mathrm{~g}$ (Table.1) of coal washery rejects along with other non-coal substrates. It revealed that anaerobic slurries CR4, CR6, CR7, and CR9 showed maximum methane production on increasing the concentration of coal. On the other hand, when the increased coal concentration of $24 \mathrm{~g}$ (CR8 and CR10) was added, the methane production starts decreasing and was found to be $17.3 \%$. Previous studies stated that this decreased methane production on increasing the coal concentration might be due to the fact that coal is the yield limiting substrate. However, they also claim that it is not toxic towards the microbial consortium (Rathi et al. 2015). Similarly, the higher amount of coal washery reject used in the current study was found to be yield restraining nutrient.

The obtained data (Fig 2) showed that when coal rejects and anaerobic sludge were mixed (CR5), the $\mathrm{CH}_{4}$ production was less $(1.8 \%)$. However, the coal washery rejects and cow dung mixture (CR4) had shown a greater $\mathrm{CH}_{4}$ production (46.8\%). Thus, it illustrates that microbial consortium present in cow dung has the highest potential to convert the coal to methane. So cow dung was found as the best consortium (Miah et al. 2016). Hence, the consortiums CR1, CR4, CR6, and CR7 which produce a high amount of methane were selected as the microbial source for the production of methane from coal washery reject as the sole carbon source.

\subsubsection{Microbial consortium from raw coal}

Four unique methanogenic consortiums from coal mines namely CR11, CR12, CR13, and CR14 were enriched in the anaerobic specific methanogenic medium. This specific medium consists of methaneproducing specific carbon sources sodium acetate, $\mathrm{H}_{2}: \mathrm{CO}_{2}$, and methanol (Susilawati et al. 2015; Rathi et al. 2015). The growth of the methanogens was confirmed by detecting the methane production after 40 days in the headspace using the gas analyzer. The maximum methane was obtained by CR11, which was found to be $22.6 \%$ (Fig. 3). This increased methane production from the CR11 sample indicates the presence of a greater number of specific methanogens that can utilize a wide range of substrates (Boone and Mah 2015). The other samples $\mathrm{CR} 13$, $\mathrm{CR} 14$, and $\mathrm{CR} 12$ produced $\mathrm{CH}_{4}$ of $12.6 \%, 9.2 \%$, and $11.0 \%$ respectively. The $\mathrm{CO}_{2}$ produced by these enriched samples CR11, CR12, CR13, and CR14 was $37.4 \%$, $15.6 \%, 20.3 \%$, and $25.6 \%$ respectively.

It has been reported that several coal samples from different origins undergo different pathways to produce methane (Barnhart et al. 2013). Most consortiums isolated from coal beds utilize $\mathrm{H}_{2}-\mathrm{CO}_{2}$ as substrate (Davis and Gerlach 2018). Surat Basin formation water utilized $\mathrm{H}_{2}-\mathrm{CO}_{2}$ and acetate substrates, where $\mathrm{H}_{2}-\mathrm{CO}_{2}$ plays a major role in methane production (Papendick et al. 2011). Hence in the current study, several available methanogenic substrates like sodium acetate, $\mathrm{H}_{2}: \mathrm{CO}_{2}$, and methanol were used to enrich the coal inoculums to produce methane. To enrich the sample collected from coal mines, 
substrates like sodium formate, sodium acetate, methanol, and $\mathrm{H}_{2}-\mathrm{CO}_{2}$ were utilized in several studies. It also helps to identify the methanogenic pathway through which the methanogens in the coal sample undergo methane production (Wei et al. 2014).

The production of methane by CR12 and CR14 samples during enrichment is low compared to other samples CR11 and CR13. These samples are also taken for further study. This is because the microbial consortium may not able to efficiently utilize the specific substrate like sodium acetate, $\mathrm{H}_{2}: \mathrm{CO}_{2}$, and methanol. However, they might have the ability to breakdown the coal into simpler compounds. Thus, we selected all the four samples CR11, CR12, CR13, and CR14 to compare the efficiency of coal enriched samples and selected non-coal consortiums CR1, CR4, CR6, and CR7 in the conversion of coal to methane.

\subsection{Comparison of coal and non-coal microbial consortiums in methane production}

A comparative study on coal and non-coal microbial consortium in methane production using coal washery reject was done. This is to identify whether the coal mines microbial consortiums have the potential to convert coal washery rejects similar to that of non-coal sources. The effect of different consortiums on the sub-bituminous coal washery rejects for methane production was evaluated. The non-coal consortiums used to study the effect of coal washery rejects as a sole carbon source were previously obtained slurries CR1, CR4 CR6, and CR7. The coal mine enriched consortia CR11, CR12, CR13, and CR14 were also taken for this study. The coal washery reject of $10 \mathrm{~g} / \mathrm{l}$ was taken as the substrate in this study. The medium used in this study contains $0.5 \mathrm{~g} / \mathrm{l}$ of yeast extract. In this study, three different sets of experiments were carried out to explore the efficiency of coal washery rejects alone in methane production.

The results revealed that the maximum of $8 \% \mathrm{CH}_{4}$ and $8.7 \% \mathrm{CO}_{2}$ was produced from cow dung (CR1) inoculums when the medium contains yeast extract and coal washery rejects. The medium with coal washery rejects alone and yeast extract alone produced $7.9 \%$ and $6.3 \% \mathrm{ff}^{\mathrm{CH}_{4}}$ which is comparatively less. The cow dung consortium works better in converting coal to methane which may be due to the surface area of cow dung which is lesser compared to that of others (Gupta and Birendra 2000).

Next to CR1 sample CR14, CR7, CR4, and CR11 sample produced maximum methane of $7 \%, 6.8 \%, 6 \%$, and $5.7 \%$ respectively while both coal washery rejects and yeast extract was present. Other samples CR6, CR12, and CR13 produced $5.6 \%, 5 \%$, and $4.3 \%$ methane respectively (Fig $4 . a$ ) at the end of 30 days. The $\mathrm{CO}_{2}$ produced by the samples were around 4.5 to $5.5 \%$ except for the cow dung alone sample (Fig $\left.4 . \mathrm{b}\right)$. It produced $\mathrm{CO}_{2}$ of around $8.7 \%$.

But on inoculating these samples in the medium containing only coal washery reject maximum of only $2 \%$ methane production was observed. It was because of the nature of the coal. Coal is a complex heterogeneous stone that has no direct substrates to be consumed by methanogenic consortiums. Methanogens can only utilize the simplest carbon sources. So to degrade the heterogeneous coal 
material complex microbes must be present in the consortium (Harlia et al. 2019). But as the medium does not contain any direct carbon sources for the growth of microbes in the consortium, it was not able to survive under this stress condition. The other reason for the reduction of methane production maybe its inhibitory effects on microorganisms (Raudsepp et al. 2017).

Here comes the role of yeast extract which can act as the source for the growth of the microbes present in the consortium. On observing the medium with yeast extract only, 2 samples (CR11 and CR4) produced maximum methane of $7.2 \%$ and $4.3 \%$. Other microbial consortium failed to produce a high amount of methane under this condition. As the medium only contains $0.5 \mathrm{~g} / \mathrm{l}$ of yeast extract which might get depleted within 30 days would be the reason for the limitation in the production of methane. So, on adding both yeast extract and coal washery rejects the production of methane is high. The additional nutrients were the rate-limiting factor in methane production. Here the yeast extract acts as the growth factor for the microbes present in the consortium that further break down the coal to produce methane (Zhang et al. 2018). Several studies also have been reported mentioning the importance of the addition of yeast extract in the basal medium for the production of methane (Rathi et al. 2015; Gray et al. 2009). The coal dependent methanogenesis process utilized yeast extract as the successful nutrient for enhanced biogenic methane production (Gilcrease 2007).

Several coal seams are of biogenic origin (Mclntosh et al. 2008) so that microbial consortium from coal mine has microbes with coal degradation features. On comparing the cow dung inoculum source (CR1) and coal mine microbial source (CR14), the production of methane from coal washery reject is nearly the same $( \pm 1 \%)$. From this, we can prove that the coal inoculum isolated from the Singreni Collieries has the potential microbes to convert the coal into methane same as that of microbes present in cow dung. Similarly, comparative studies have been done to demonstrate the efficiency of several microbial consortiums from coal formation water and mangrove swamps on converting brown coal into methane (Wang et al. 2016).

From the results obtained during the enrichment of the coal sample, CR14 sample produced less methane compared to CR11, CR12, and CR13. However, when the CR14 enriched sample was utilized in converting coal to methane it ranks first in the production of methane compared to others. This is due to the fact that the CR14 consortium has the better potential to biodegrade the coal into simpler compounds than others (Rathi et al. 2015). This increased yield of methane during the utilization of coal as the carbon source might be also due to the bioavailability of coal towards the microbes.

\section{Conclusion}

In this study, the efficiency of coal enriched microbial consortium is compared with several non-coal anaerobic consortiums in converting coal washery rejects into methane. There are reports where various coals such as lignite, bituminous, and coal waste materials have been utilized for methane production. The results indicate that coal waste material produced methane equal to that produced by bituminous coal (Opara et al. 2012). So insights into the production of methane from the coal washery reject using 
various inoculums have been demonstrated in the current study. Further to enhance the methane production from coal washery rejects, the mixture of microbial consortium from coal and non-coal inoculums will be taken into concern for future studies.

\section{Declarations}

Funding The research leading to these results received funding from Department of Science and Technology (DST), Government of India under Grant Agreement No TMD/CERI/ Clean coal/ 2017/012 dated 26-04-2019.

Conflicts of Interest The authors have no conflicts of interest to declare that are relevant to the content of this article.

Availability of data and materials Not Applicable

Code Availability Not Applicable

Ethics Approval Not Applicable

Informed Consent Not Applicable

Acknowledgments We are grateful to Bannari Amman Institute of Technology for providing the laboratory facilities to execute this study. We are also thankful to the Department of Science and Technology (DST), Government of India for the financial support for this study (TMD/CERI/ Clean coal/ 2017/012 dated 2604-2019).

\section{References}

Babel S, Sae-Tang J, Pecharaply A (2009) Anaerobic co-digestion of sewage and brewery sludge for biogas production and land application. Int. J. Environ. Sci. Technol. 6:131-140. https://doi.org/10.1007/BF03326067

Barnhart EP, De León KB, Ramsay BD, Cunningham AB, Fields MW (2013) Investigation of coal-associated bacterial and archaeal populations from a diffusive microbial sampler (DMS). Int. J. Coal Geol. 115:6470. https://doi.org/10.1016/j.coal.2013.03.006

Boone DR, Mah RA (2015) Methanosarcina, in: Bergey's Manual of Systematics of Archaea and Bacteria. John Wiley \& Sons, Ltd, Chichester, UK, pp. 1-15. https://doi.org/10.1002/9781118960608.gbm00519

Coal Statistics, Ministry of coal, Government of India, (2018-19).

https://www.coal.nic.in/sites/upload_files/coal/files/coalupload/AnnualReport1819.pdf. Accessed on 28.02.2019. 
Coal in the energy supply of India, International Energy Agency IEA (2002). Coal Industry Advisory Board. Available at https://www.iea.org/areas-of-work/industry-engagement/coal-industry-advisory-Board.

Davis KJ, Gerlach R (2018). Transition of biogenic coal-to-methane conversion from the laboratory to the field: A review of important parameters and studies. Int. J. Coal Geol. 185:33-43.

https://doi.org/10.1016/j.coal.2017.11.006

Energy Statistics 2019, Ministry of statistics and programme implementation, Government of India.http://www.mospi.gov.in/sites/default/files/publication_reports/Energy\%20Statistics\%202019finall.pdf Accessed on 01 March 2021.

Flores RM, Rice CA, Stricker GD, Warden A, Ellis MS (2008). Methanogenic pathways of coal-bed gas in the Powder River Basin, United States: The geologic factor. Int. J. Coal Geol. 76:52-75. https://doi.org/10.1016/j.coal.2008.02.005

Fuertez J, Nguyen V, McLennan JD, Adams DJ, Han KB, Sparks TD (2017). Optimization of biogenic methane production from coal. Int. J. Coal Geol. 183:14-24. https://doi.org/10.1016/j.coal.2017.09.014

Gaur RZ, Suthar S (2017). Anaerobic digestion of activated sludge, anaerobic granular sludge and cow dung with food waste for enhanced methane production. J. Clean. Prod. 164:557-566. https://doi.org/10.1016/j.jclepro.2017.06.201

Gupta A, Birendra K. (2000). Biogasification of coal using different sources of micro-organisms. Fuel 79:103-105. https://doi.org/10.1016/S0016-2361(99)00097-6

Hasan MA, Aqsha, Putra ZA, Bilad MR, Sapiaa NAH, Wirzal MDH, Tijani MM (2018). Biogas production from chicken food waste and cow manure via multi-stages anaerobic digestion. p. 020011. https://doi.org/10.1063/1.5055413

Jones EJP, Voytek MA, Warwick PD, Corum MD, Cohn A, Bunnell JE, Clark AC, Orem WH (2008). Bioassay for estimating the biogenic methane-generating potential of coal samples. Int. J. Coal Geol. 76:138-150. https://doi.org/10.1016/j.coal.2008.05.011

Lavania M, Cheema S, Sarma PM, Ganapathi R, Lal B (2014). Methanogenic potential of a thermophilic consortium enriched from coal mine. Int. Biodeterior. Biodegradation 93:177-185.

https://doi.org/10.1016/j.ibiod.2014.05.022

Lei Z, Chen J, Zhang Z, Sugiura N (2010). Methane production from rice straw with acclimated anaerobic sludge: Effect of phosphate supplementation. Bioresour. Technol. 101:4343-4348. https://doi.org/10.1016/j.biortech.2010.01.083

Li W, Siddhu MAH, Amin FR, He Y, Zhang R, Liu G, Chen C (2018). Methane production through anaerobic co-digestion of sheep dung and waste paper. Energy Convers. Manag. 156:279-287.

https://doi.org/10.1016/j.enconman.2017.08.002

Page 13/18 
Liu L, Zhang T, Wan H, Chen Y, Wang X, Yang G, Ren G (2015). Anaerobic co-digestion of animal manure and wheat straw for optimized biogas production by the addition of magnetite and zeolite. Energy Convers. Manag. 97:132-139. https://doi.org/10.1016/j.enconman.2015.03.049

McIntosh J, Martini A, Petsch S, Huang R, Nüsslein K (2008). Biogeochemistry of the Forest City Basin coalbed methane play. Int. J. Coal Geol. 76:111-118. https://doi.org/10.1016/j.coal.2008.03.004

Miah MR, Rahman AKML, Akanda MR, Pulak A, Rouf MA (2016). Production of biogas from poultry litter mixed with the co-substrate cow dung. J. Taibah Univ. Sci. 10:497-504.

https://doi.org/10.1016/j.jtusci.2015.07.007

Opara A, Adams DJ, Free ML, McLennan J, Hamilton J (2012). Microbial production of methane and carbon dioxide from lignite, bituminous coal, and coal waste materials. Int. J. Coal Geol. 96-97:1-8. https://doi.org/10.1016/j.coal.2012.02.010

Papendick SL, Downs KR, Vo KD, Hamilton SK, Dawson GKW, Golding SD, Gilcrease PC (2011). Biogenic methane potential for Surat Basin, Queensland coal seams. Int. J. Coal Geol. 88:123-134. https://doi.org/10.1016/j.coal.2011.09.005

Qaisar Shadman Hussain AMA (2014). Production, Consumption and Future Challenges of Coal in India. Int. J. Curr. Eng. Technol. 4:3437-3440.

Rathi R, Priya A, Vohra M, Lavania M, Lal B, Sarma PM (2015). Development of a microbial process for methane generation from bituminous coal at thermophilic conditions. Int. J. Coal Geol. 147-148:25-34. https://doi.org/10.1016/j.coal.2015.06.004

Susilawati R, Golding SD, Baublys KA, Esterle JS, Hamilton SK (2016). Carbon and hydrogen isotope fractionation during methanogenesis: A laboratory study using coal and formation water. Int. J. Coal Geol. 162:108-122. https://doi.org/10.1016/j.coal.2016.05.003

Wang B, Tai C, Wu L, Chen L, Liu J, Hu B, Song D (2017). Methane production from lignite through the combined effects of exogenous aerobic and anaerobic microflora. Int. J. Coal Geol. 173:84-93. https://doi.org/10.1016/j.coal.2017.02.012

Wang B, Wang Y, Cui X, Zhang Y, Yu Z (2019). Bioconversion of coal to methane by microbial communities from soil and from an opencast mine in the Xilingol grassland of northeast China. Biotechnol. Biofuels 12, 236. https://doi.org/10.1186/s13068-019-1572-y

Wang H, Lin H, Rosewarne CP, Li D, Gong S, Hendry P, Greenfield P, Sherwood N, Midgley DJ (2016). Enhancing biogenic methane generation from a brown coal by combining different microbial communities. Int. J. Coal Geol. 154-155:107-110. https://doi.org/10.1016/j.coal.2015.12.006

Wei M, Yu Z, Jiang Z, Zhang H (2014). Microbial diversity and biogenic methane potential of a thermogenic-gas coal mine. Int. J. Coal Geol. 134-135:96-107. 
Zhang J, Liang Y (2017). Evaluating approaches for sustaining methane production from coal through biogasification. Fuel 202:233-240. https://doi.org/10.1016/j.fuel.2017.04.037

Zheng H, Chen T, Rudolph V, Golding SD (2017). Biogenic methane production from Bowen Basin coal waste materials. Int. J. Coal Geol. 169:22-27. https://doi.org/10.1016/j.coal.2016.09.006

\section{Figures}

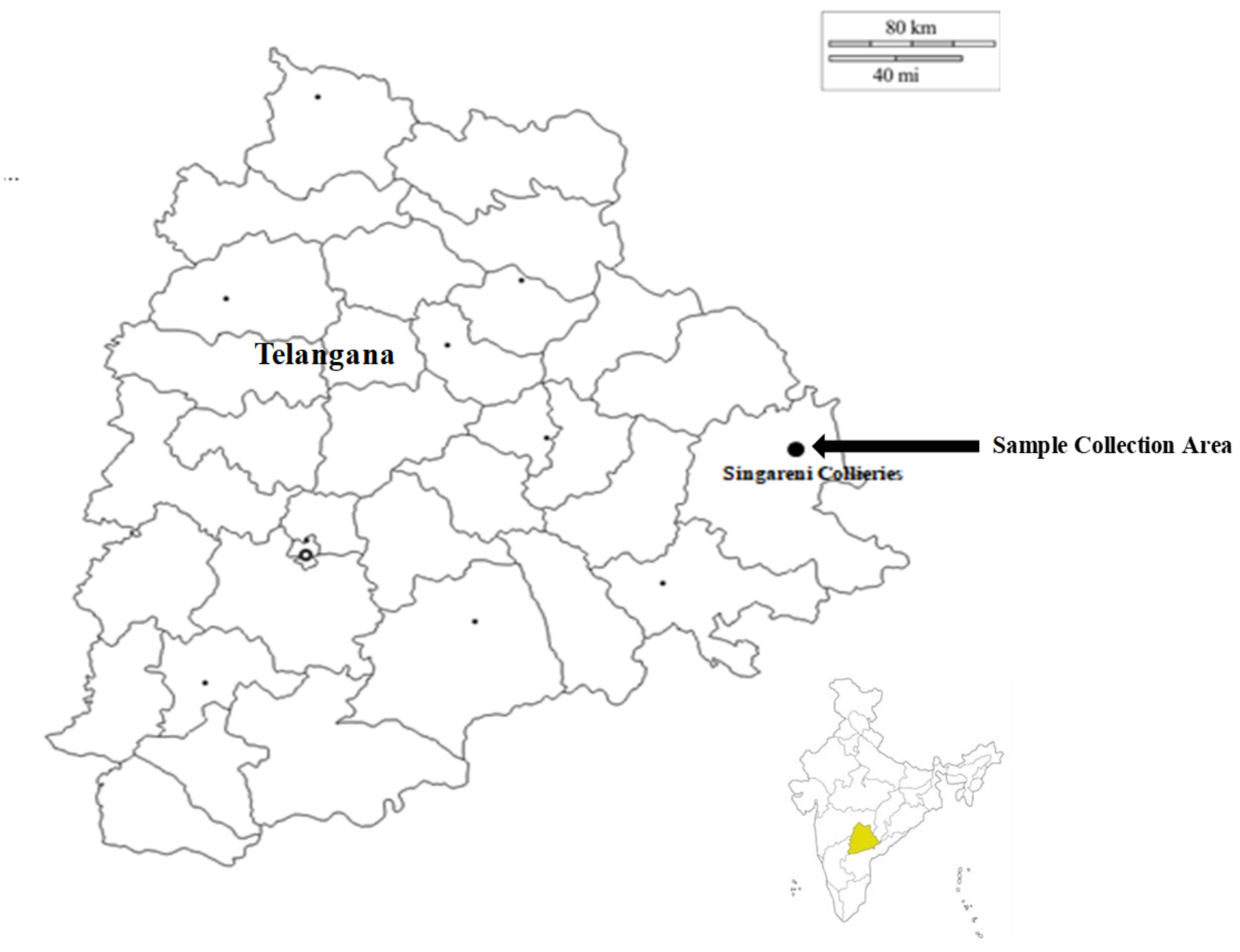

Figure 1

Location of Singareni Collieries Company Ltd (SCCL) for collection of coal washery rejects. Note: The designations employed and the presentation of the material on this map do not imply the expression of any opinion whatsoever on the part of Research Square concerning the legal status of any country, 
territory, city or area or of its authorities, or concerning the delimitation of its frontiers or boundaries. This map has been provided by the authors.

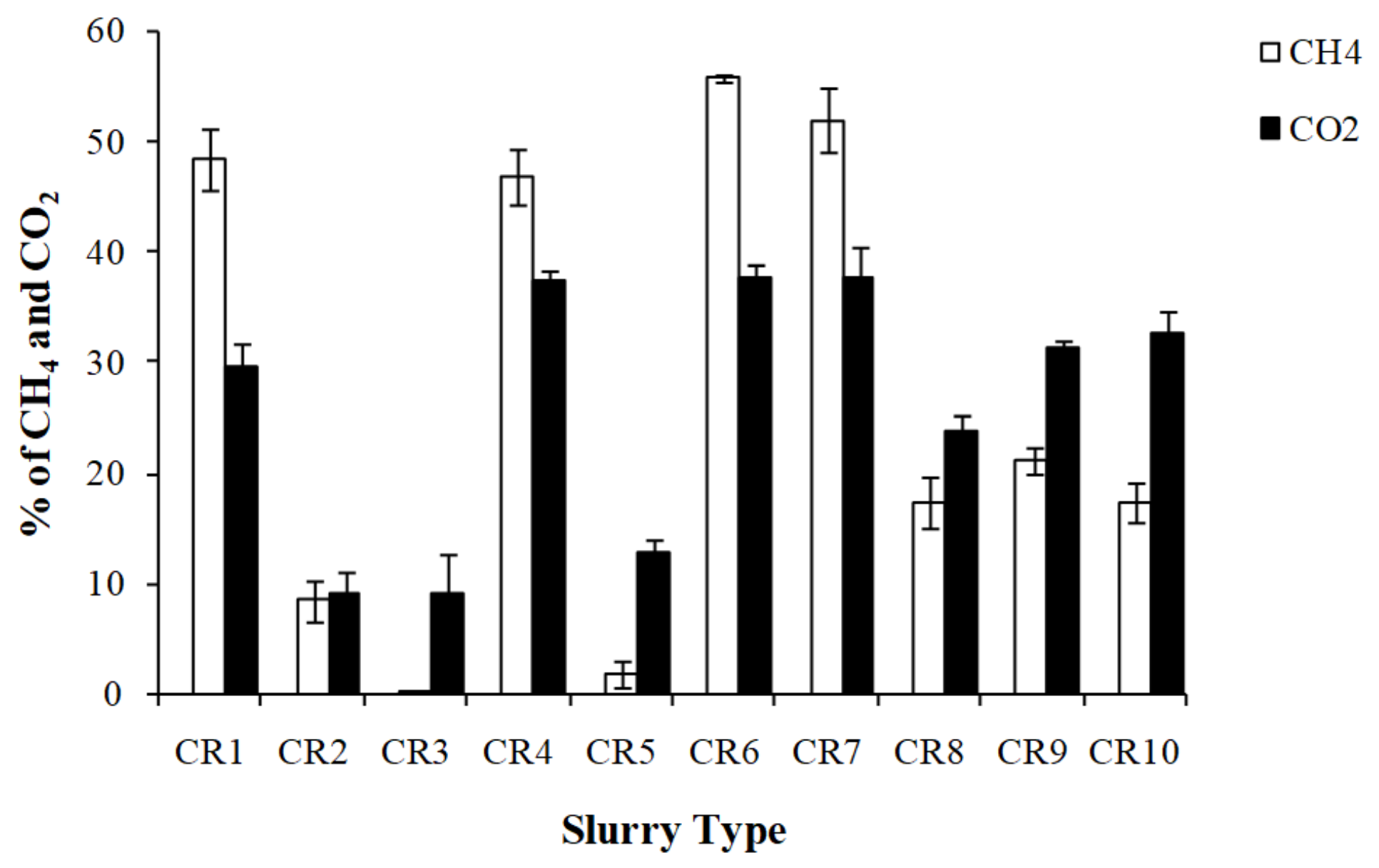

Figure 2

$\mathrm{CH} 4$ and $\mathrm{CO} 2$ generated during the anaerobic process of various non-coal microbial sources with coal washery rejects. 


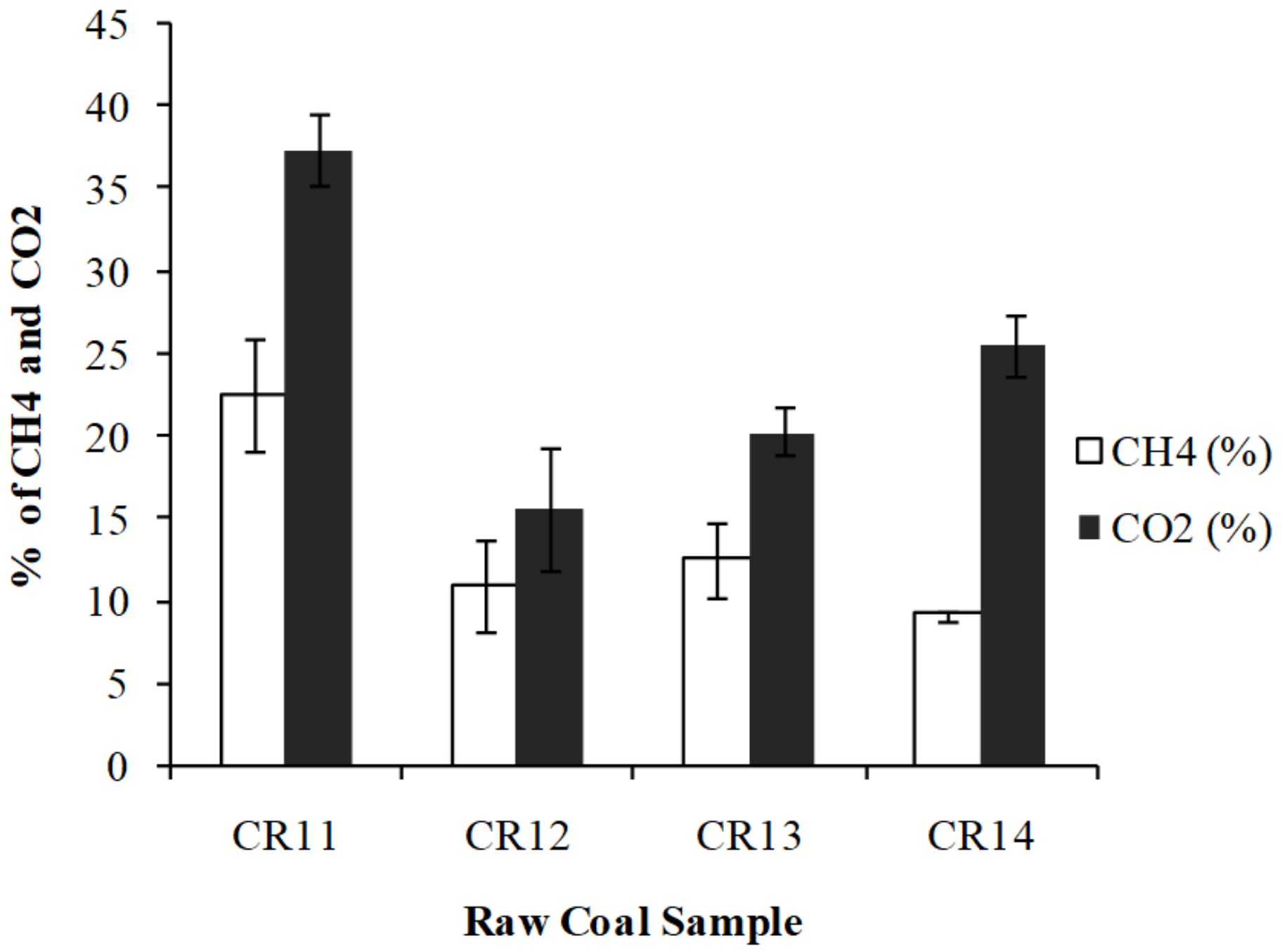

Figure 3

Production of $\mathrm{CH} 4$ and $\mathrm{CO} 2$ by microbial consortia CR11, CR12, CR13, and CR14 obtained from raw coal of Singareni Coal mines. 

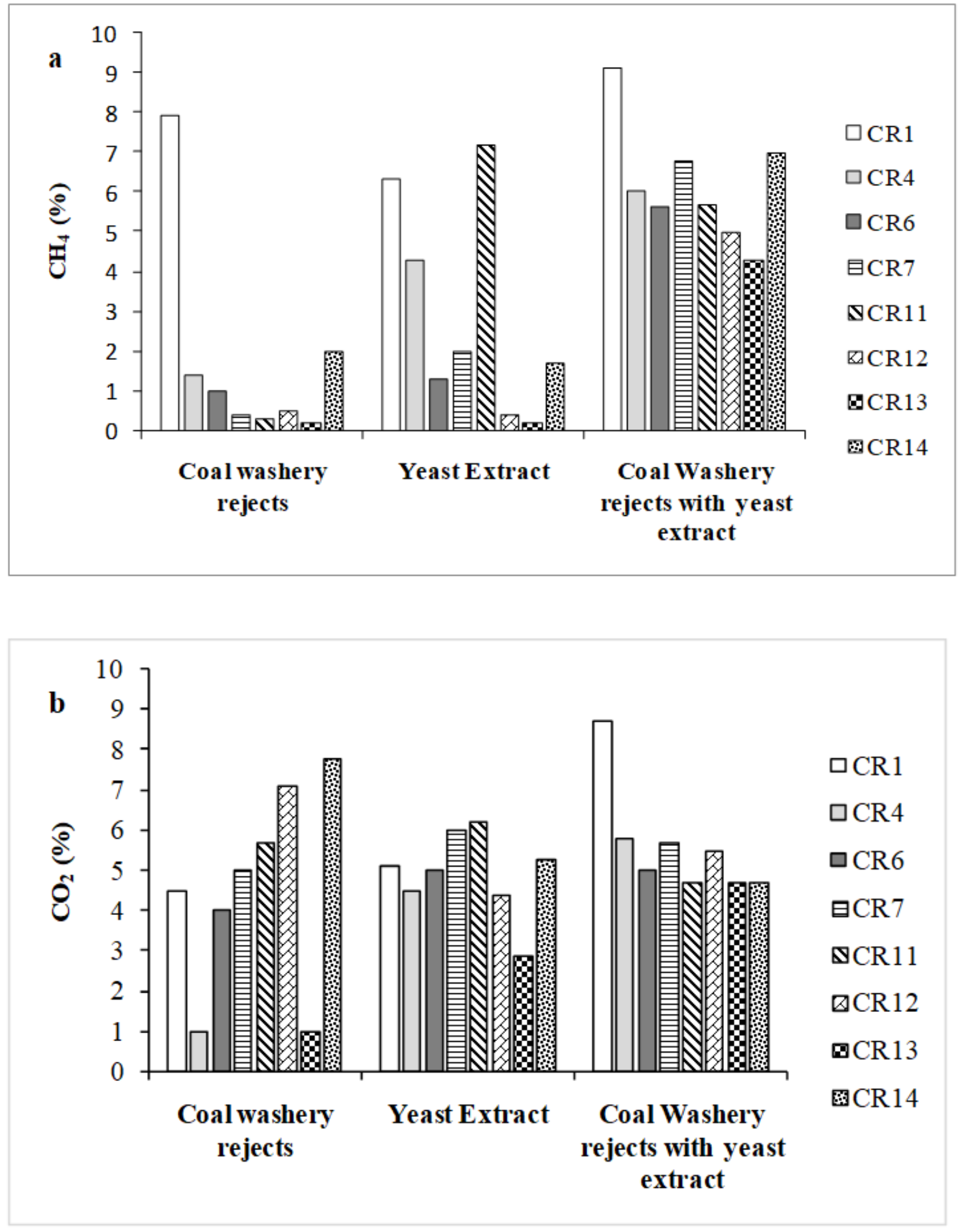

Figure 4

Effect of coal and non-coal microbial consortiums on the conversion of coal to methane and carbon dioxide. a. Percentage of methane $(\mathrm{CH} 4)$ production using various carbon sources. b. Percentage of Carbon dioxide production using various carbon sources. 